\title{
Immense Power of English Language: Shall our Teachers Exploit or Avoid it?
}

\author{
Govinda Raj Bhattarai \\ Tribhuvan University \\ tu.govinda@gmail.com
}

\section{Abstract}

We have realized the importance of English. About 150 years of English courses in Nepal has proved this. Yet we have not reached the desired level of it. All the efforts made by Nepal English Language Teachers' Association (NELTA) are to promote and improve English in terms of its quality and quantity both. We need more English, better English, faster and deeper every decade at the cost of the national language. Even we need it at the cost of the languages of the nation. They have already suffered a great loss by yielding before English at the cost of everything, specially, the culture. But our efforts are focused on a stereotype of English, teaching some rules of second language teaching and learning. Underpinned heavily by theories of educational psychology, our English teaching is rule governed so our students do not see, feel, and touch the depth of real English. That is, because our focus is on teaching a special kind of English that is constrained to grammar, vocabulary and pronunciation. All structural things, all basic. Other nations have exploited English for diverse purposes. One among them being reading and writing; creative works and practicing translation of our languages. Thus, in this short write up, I have traced the importance of English to Nepalese learners in its different dimensions of use.

Keywords: translation, transcription, transcultural, transliteration, deconstruction, ecological encroachment

\section{Prelude}

The present day world civilization is steered by translation. For instance, Olga Tokarjuk obtained Nobel Prize 2018 for her Polish novels translated into English. As a result, her translator Jenifer Croft became as popular as the author herself. (Tokarjuk thanked even her translator in her Nobel Speech). Similarly, Svetlana Alexievich was awarded Nobel Prize for 2015. She got this because of the English translations of Belorussian novels carried out into English by Keith Gessen. In the same way, Mark Polizotti translated the French works of Patrick Modiano, the Nobel Laureate of 2014 into English. Who can do this job in Nepal? Although 
there is no dream of winning such covetous prizes for a Nepali writing however we need to nurture a hope even for a distant dream. Moreover, we must commit ourselves to serve the nation by doing translation. Otherwise, how can we promote our national image? Whose responsibility is this? I know this is the responsibility of those who are teaching and learning English. What are we teaching if our students of English language cannot make any such contribution? I believe time has come to think more seriously over this matter. NELTA should produce really good and great bilinguals (translators) and not only school teachers. I know this should be the responsibility of those who are teaching and learning English in this nation. What are we teaching if our students of English language cannot make any contribution towards the promotion of literature?

Now our institutions like Department of English (both) should produce such candidates who can uplift the fate of their mother tongues by bringing them to the fore. In a 1953 conference held at Tashkent of Uzbekistan, Nepali Mahakavi, Laxmi Prasad Devkota put three points there-one of them was national literature is lagging behind because there is lack of translation activity. The present paper has discussed this issue.

\section{Objective}

The objective of this paper is to exemplify our audiences that though we spend large amount of time and money in order to furbish our professional life through English, with English and for English, we do not know what it is for. Is it just for teaching only or are there any other special avenues lying unused that we can access with English?

\section{The Value of English and Translation}

There are many areas under the umbrellas of EAP and ESP which contain uncountable professions and hobbies that English language can serve. One of the most promising lands which is a different type of creative art most suitable for us English language teachers is translation. In other languages too English translation is the choicest of all languages used for translating national literatures for others or introducing international literatures into one's own treasure. So our courses should teach translation theory and involve our learners in its practice.

Translation is the most difficult task of giving new life to a dormant thing, that is, a foreign language which is an unquarried mine of gems until we excavate and unearth. It is dormant and latent for the society that does not enjoy the original writings in that language. At least some torch bearers should know first 
of all that there lies a valuable mine. And such torch bearers are only language teachers who have some knowledge of both languages. The creation for the mass is like a foreigner in his/her own garb. So it needs some changes of dress, locale, voice and geography which does not match with that of the recipient society. So it should be accepted with full understanding that it is a foreigner friend and needs our love and honor. Then only she will perform her skill and reveal the secret art-of satisfying the users. Only a few torch bearers possess intent, interest, knowledge and patience that can help master this art and give result a different identity, a different membership, a dual characteristics, in fact a dual citizenship. How happy we are to read Tolstoy's War and Peace, Gorky's My Childhood Days, Herman Hessey's The Siddhartha, or Selected Poems of Emily Dickinson... There are more than 500 of such foreign friends in our own tongue. The Nepali translation of Macbeth can be taken as a sample or most widely read Old Man and the Sea or The Good Earth.

This is a two way traffic. The process may be reversed-taking from one's own language a piece of best work, for instance, Seto Dharti or Sukaratka Paila and put a new garb and let them join the foreign flock. Though translation is never an act of naturalization nor an act of foreignization. Its identity is always a translation, a guest of in-between position. Some claim that this translation reads like the original. Or as good as original. No, this is a mistaken concept. It should be a good translation. That's all.

\section{Nepal's Case}

Nepal Academy has recently published A Directory of Translators (2018) which contains altogether 620 translators one of whose language must be Nepali. This shows that famed teachers like Mahakavi Devkota, Taranath Sharma, T R Kansakar, Shantadas Manandhar, Khagendra Sangraula, Robin Sharma, Abhi Subedi, Ananda Shrestha, more than half the total number are teachers. They have contributed most among others and have been listed among the immortal figures of Nepal. There are young generation forerunners already earning name and fame, both in translation though with very little money. In a backward nation like ours one cannot earn money from mental works like a helmet teacher does, like a guide book writer does, like a tuition master does. But translation enlists his/her name among those great persons that served the nation by using their bilingual spirit. History will honor them though they are pearls cast before the swine. They are language users and somehow bilinguals. Upon their shoulder lies the task of translating from and to other languages. They know the function of language and intricacy of it. They know the style and art that language can 
perform. They know how a language performs magic at the highest level. Because they are facing language problems and lured by the art of expression throughout their lives. Isn't the art of expression an area suitable for a language teacher?

\section{Translation at Home}

Last year I went to my village and saw that one of my daughters in law is teaching English to her small daughter by illustrating the object of translation. The conversation went like this

D: Mommy kera, mommy kera khane.

M. (carrying a banana in her hand-kera hoina banana bhannu

hos. It is a banana. Tapailaai skulmaa misle sikaaunuhunna?

D: Nai Kera khaane. Mommy and she began to cry.

M: Kera hoina banana bhannu hos ani dinchhu.

D: Mommy banana khnae.

M: Then she was given a banana.

She was a wonderful teacher though hardly literate. They lure their children to unlearn their native tongue and learn more English, all English, total English through direct translation method. By tempting or luring through the crudest method appealing to their heart, they have distorted language and are producing aliens at every household. This is the spell of English and they are colonizing every household. It is not better to blame the British rulers now. We are doing this colonization business ourselves. We love to be enslaved by thwarting our languages and cultures.

While I was writing these sentences, the mobile tone rang and saw a quotation flashing on the screen Love is the absence of judgment. The most designed gift of love is not diamonds or roses or chocolate. It is focused attention. The first one was the Dalai Lama's exhortation. The second words of wisdom by Rick Warren. We can compare the mother's broken English and the baby's focused attention on to the kera.

I suggest, my friends, to go through a number of works and see how social values are changing faster than anything by destroying all cultural heritages and how the society is lured by English - for more of it, all of it. 
This crave has brought equality and has helped uplift the downtrodden as English is being a neutral to our cultural orientation. In Nepal they love to take shelter of this and embrace this as a savior. They want to shed off the value loaded customs and traditions attached to Nepali language which prove tortuous to them. This desire is a complete departure from social tradition so even the prime minister expressed his ire at the use of timi (you) at the cost of honorific tapain in the journalese. English has brought this great change in our social order. It has encroached our cultural norms which is the unwanted intervention cultural ecology.

We experience great departures, great breakdowns and social upheavals. Undefined dreams shaking and breaking the young generation. The growing number of English schools, the growing number of parents who loved to be fleeced who want to wear a different mask and look different in society is a popular scene today. So, my suggestion is to be guided properly by using English for desirable results instead of using this for creating a fake society.

\section{Translation and English}

Most of world's languages use English as a medium of translation. It is most widely spread and is considered as a language of power and prestige. It is also a strong vehicle of modern knowledge and technology. Especially, it is the language of the digital technology. Not only because of this but because of its great treasure of literature the world is always eager to read Shakespeare and Milton, James Joyce and Virginia Woolf.

There are great awards and prizes with large amount of money like Nobel Prize, Pulitzer Prize, Man Booker Prize that operate with English and for English. Pulitzer Prize was established in the USA and Man Booker in the UK. These promote English - all creative. Olga Tokarjuk, the Nobel Laurite of 2018 won Man Booker Prize for her novel Flights which was just translated by Jennifer Croft. It must be presented in English-originally authored or translated into it. She received the amount of nearly one crore and it was divided between Olga and her translator Croft. It is delighting to know that as the author wins the translator too has her share-half of it.

In case of Nobel Prize there is no mandatory language but unless one gets translated into major languages, especially English, there is no possibility of winning the prize. And there are great translators who render into English from different languages. 


\section{A Mark of Success}

A nation's pride is measured in its efforts to perform and preserve works of art. The perfection of art works leads a nation to a cultured position and to a higher echelons of civilization. The more we ignore art, the more we are ignored by the world. A nation's richness and pride are measured by translation. Now there is a computer program through which we can measure the worth of a nation. A great French composer Jean Sibelius has said A Statue Has Never Been Set Up in Honor of a Critic. The world may claim A statue has never been set in honor of a teacher. This is quite disappointing thing. But its suggestion is let us do something great with the power of language that we possess apart from teaching. Together with teaching so that it lasts long.

\section{Some Examples}

I present you some eminent writers whose works have been translated into more than 20 languages. One can search for the writers of his interest and find wonderful facts in world catalogue identity programme.

1. INDIA-- Rabindranath Tagore's creative works are translated into 58 languages and they are available in 1, 39, 106 libraries of the world.

2. ENGLAND-William Shakespeare's creative works are translated into 99 languages and they are available in 52, 59, 400 libraries of the world.

3. RUSSIA-Leo Tolstoy's creative works are translated into 55 languages and they are available in 5, 39, 681 libraries of the world.

4. PERSIA-Omar Khayyam's Tagore's creative works are translated into 44 languages and they are available in 61,482 libraries of the world.

5. USA-Toni Morrison's creative works are translated into -44 languages and they are available in 7, 70, 656 libraries of the world.

6. UK-J K Rowling's creative works are translated into 57 languages and they are available in 3, 04, 706 libraries of the world.

7. CHINA-Mo Yan's creative works are translated into 16 languages and they are available in 30, 956 libraries of the world. 
8. NEPAL-Mahakavi Laxmi Prasad Devkota's creative works are translated into 3 languages and they are available in 765 libraries of the world.

9. NEPAL-Govinda Raj Bhattarai's creative works are translated into 2 languages and they are available in 487 libraries of the world.

10. POLAND-Olga Tokarjuk's creative works are translated into 31 languages and they are available in 5,897 libraries of the world. (2018 Nobel league)

\section{Conclusion}

In this way, a nation's glory is connected with the creative use of the particular language, and powerful creative works first of all. Powerful writing calls for powerful translation. It is only translation that releases one from the imprisonment, brings himself /herself to an open, wider world. So that the world can look at his/her face first then they look at the nation to which they were born. They look at the language which comes from that geography.

My ultimate suggestion, here is please, appeal request and entreaty is to do something permanently while we possess this powerful weapon-English language.

\section{References}

Bhattarai, G. R. (2004). An introduction to translation studies. Kathmandu: Ratna Pustak Bhandar.

Bhattarai, G. R. (1996). Sense verses words: The unit of translation (with reference to Neplai English poetic texts). An Unpublished PhD Dissertation, University of Hyderbad, India.

(Beisdes these, I have used the following titles preparing the paper as a background: In Other Word: A Coursebook on Translation by Mona Baker, Translation Studies by Susan Bassnett, Translation Studies Reader by Lawrence Venutti, Routledge Encyclopedia of Translation, and Studies, Experinces in Translation Studies by Umberto Eco). 